\title{
VEN AND FREQUENCY ANALYSIS OF THE QUALITY OF PHARMACOTHERAPY OF PATIENTS WITH CHRONIC HEPATITIS
}

\author{
O.V.Tkachova, N.T.T.Fung, I.V.Zavadska*
}

National University of Pharmacy
SE «Dnipropetrovsk Medical Academy»*

Key words: drugs for the treatment of chronic hepatitis; analysis of the quality of treatment

\begin{abstract}
VEN and frequency analysis were used to analyze the quality of pharmacotherapy of 79 patients with chronic hepatitis $(\mathrm{CH})$ who were treated in a healthcare institution (HCI) in the city of Dnipropetrovsk in 2015. It has been found that pharmacotherapy at the HCI corresponded to main areas of the treatment specified in the clinical protocol of medical care (CPMC) to patients with CH. It has confirmed the rationality of drug prescriptions. However, a significant number of prescriptions per a patient (on average 8.9 drugs) indicates the polypharmacy in this department of the HCI. Moreover, according to the results of the formal VEN analysis a significant number of drugs with the index $N$ (non-essential drugs) has been determined; it indicates the need for correction of drug prescription by doctors at this HCI in accordance with the current science-based medical regulations - the National Drug Formulary of Ukraine (the $7^{\text {th }}$ edition) and the CPMC to patients with $\mathrm{CH}$ - by reducing prescriptions of non-essential drugs that are not included in these regulations. Today, being developed 11 years ago, the CPMC to patients with $\mathrm{CH}$ needs to be updated since it does not meet modern requirements to the current science-based medical practice guidelines that allow making the best clinical decisions in favour of the patient in accordance with the requirements of evidence-based medicine.
\end{abstract}

Chronic liver diseases are one of the most acute problems of modern gastroenterology. Annually 5\% of the world population that exceeds 3 billion people suffer from chronic hepatitis $(\mathrm{CH})$ [2]. In Ukraine, for the past 10 years, the prevalence of $\mathrm{CH}$ increased by at least $2.5 \mathrm{ti}$ mes [8]. The above facts demonstrate the importance of the problem of timely diagnosis and pharmacotherapy of hepatitis to improve organization of the specialized medical care, which has not only medical, but also social and economic significance [10].

The results of research and practical medicine show that patients with $\mathrm{CH}$ are at high risk of progression of the disease in liver cirrhosis and hepatocellular carcinoma [9]. Cirrhosis of the liver is one of the major causes of death of the population and occupies the 4 th place in the structure of cau- ses of death in US men over 40 [6]. In recent years in Ukraine there is a tendency to increase in morbidity and mortality from liver cirrhosis. This situation calls for the optimization of treating patients in healthcare institutions (HCI) by assessing the compliance of the $\mathrm{CH}$ pharmacotherapy with regulatory requirements of the Ministry of Health of Ukraine, i.e. by evaluating the quality of pharmacotherapy.

The aim of the study is to analyze the quality of the $\mathrm{CH}$ pharmacotherapy in patients in a hospital using VEN and frequency analysis in order to assess how well the pharmacotherapy has been conducted, or whether it corresponds to the current level of medical science and practice.

\section{Materials and Methods}

To achieve this goal it was necessary to perform the following

O.V.Tkachova - Doctor of Pharmacy, associate professor of the Department of Pharmacoeconomics of the National University of Pharmacy (Kharkiv)

I.V.Zavadska - teaching assistant of the Department of General and Clinical Pharmacy of the Dnipropetrovsk Medical Academy

tasks: 1) to conduct a retrospective analysis of the medication administration records of patients with chronic hepatitis; 2) to determine the frequency of prescriptions of drugs to patients with $\mathrm{CH}$; 3 ) according to the results of the formal VEN analysis to assess the compliance of the $\mathrm{CH}$ therapy with the regulatory requirements of medical and technological documents of the Ministry of Health of Ukraine: the National Drug Formulary (NDF) and the clinical protocol of medical care (CPMC) to patients with $\mathrm{CH}$ [4] and comorbidities. Upon condition that the drug is recommended for the treatment of this disease by the regulation, the index V (vital) will be assigned to it, and in case of the absence of the drug in the regulation the index $\mathrm{N}$ (non-essential) [5]. From medical and technological regulations the NDFU $\left(7^{\text {th }}\right.$ edition, 2015) and the CPMC to patients with $\mathrm{CH}$ [4] and other CPMC to patients with comorbidities were used in the study.

The retrospective clinical and economic analysis of prescriptions was conducted on the basis of 
79 case histories of patients with $\mathrm{CH}$, who during 12 months (January - December 2015) were treated in the Department of Gastroenterology of one of the $\mathrm{HCI}$ in the city of Dnipropetrovsk.

\section{Results and Discussion}

The main diagnosis in 66 patients is chronic hepatitis of the non-viral etiology and in 13 patients - chronic toxic hepatitis. Hereinafter, we combine both names of the disease under the single term "chronic hepatitis" (CH). The age of patients with $\mathrm{CH}$ ranged from 16 to 82 (79 patients included 35 women and 44 men). The average period of stay of the patient in the hospital was 16 days. In the case histories studied the following concomitant diagnoses, except for $\mathrm{CH}$, were indicated: chronic cholecystitis ( $57 \%$ of patients), chronic pancreatitis (56\% of patients), gastroduodenitis $(15.2 \%$ of patients), hepatic encephalopathy (11.4\% of patients), GERD (6.4\% of patients), and ulcerative colitis (3.8\% of patients).

According to recommendations of the CPMC to patients with $\mathrm{CH}$ (Annex to the Order of the Ministry of Health No. 271 dated 13.06.2005) the $\mathrm{CH}$ therapy should be aimed at elimination of toxins from the body due to introduction of detoxification solutions (Rheopolyglucin, Rheosorbilact, $5 \%$ glucose solution, etc.); normalization of the gastrointestinal tract through the prescription of probiotics, enterosorbents, enzyme drugs and vitamins; restoration of the liver function by prescribing hepatotropic drugs and maintaining a diet (diet No. 5) excluding fried, salted, pickled, fatty and spicy dishes.

The analysis of case histories of patients with $\mathrm{CH}$ showed that 118 trade names (TNs) of drugs and 12 dietary supplements were prescribed to patients. The ratio of foreign and domestic drugs was $2: 1$. All drugs were referred to 38 INNs and 35 pharmacological

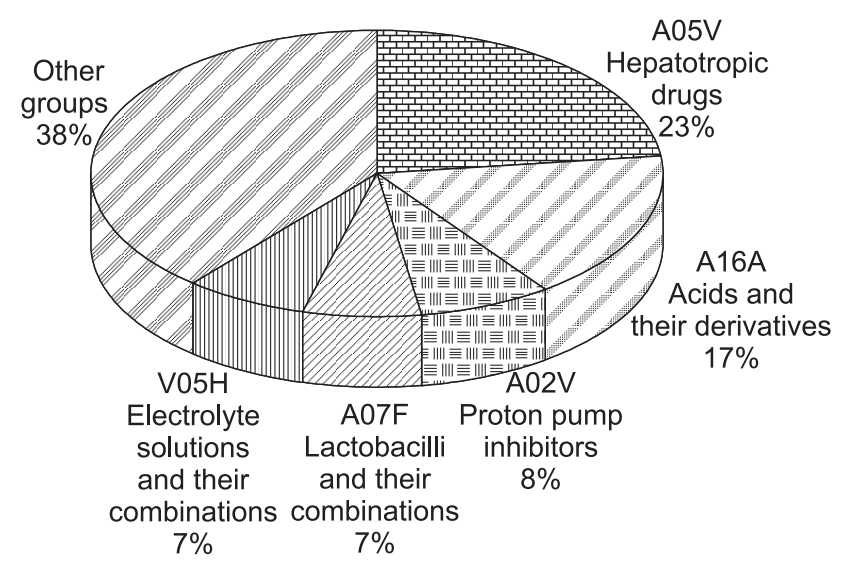

Fig. 1. Leaders by prescription among the ATC groups

groups. To treat the underlying disease 43 TNs assigned to 8 pharmacological groups were used from all drugs prescribed. To treat comorbidities 87 TNs of drugs from 27 pharmacological groups were prescribed to patients.

During the study period 700 prescriptions of drugs to all patients with $\mathrm{CH}$ were registered in this department; it was an average of 8.9 drugs per a patient and indicating the polypharmacy. According to recommendations of the CPMC to patients with $\mathrm{CH}$ (Annex to the Order of the Ministry of Health No. 271 dated 13.06.2005) [4], 4-5 INNs of drugs are used for pharmacotherapy of the underlying disease that can be characterized as pharmacotherapy, which corresponds to the WHO requirements.

In this department the prevailing areas of therapy of patients with $\mathrm{CH}$ were detoxification therapy (salt, detoxification solutions, glucose solutions) and pathogenetic therapy of the underlying disease (vitamins, probiotics, enterosorbents, hepatotropic drugs), which corresponded to the CPMC to patients with $\mathrm{CH}$ applicable at the time of study. The prevailing areas of pharmacotherapy of the concomitant gastroenterological disease were proton pump inhibitors for chronic cholecystitis and pancreatitis (Nolpaza, Controloc). Fig. 1 shows the proportion of each pharmacological group of drugs (\%) in the total number of prescriptions to patients with $\mathrm{CH}$ for 5 top leaders. The results of frequency analysis showed that the doctors in the department often preferred imported drugs as most TNs of leading drugs by the frequency of prescriptions were of foreign manufacturers.

Fig. 2 shows 10 top leaders among TNs by the frequency of prescription in the HCI. Among them the majority was used in the regimens of the complex therapy of patients diagnosed with $\mathrm{CH}$ (HepaMerz, Cytoflavin, 5\% glucose solution, Phosphogliv, Hepadif, Lacium, Ursolisin), it was consistent with the CPMC data. But taking into account that the CPMC to patients with TH was drawn up 11 years ago (2005) today it does not meet the current requirements to sciencebased medical information, which allows making the best clinical decisions in favour of the patient. Current requirements of evidence-based medicine provide for continuous improvement of measures for diagnosis, treatment and prevention of diseases. For this purpose, it is necessary to introduce a new improved CPMC to patients suffering from chronic hepatitis of the non-viral etiology, and it should include methods of diagnosis and pharmacotherapy of hepatitis caused by drug-induced injury and hepatitis caused by injury from toxic substances (e.g., benzene, lead, pesticides, etc.). The new unified CPMC to patients suffer- 


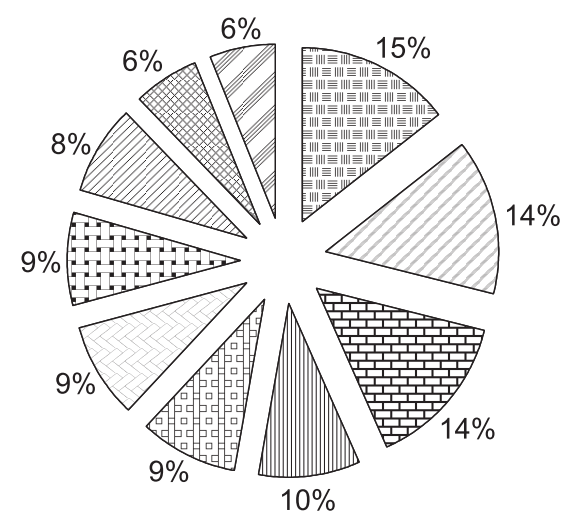

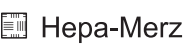

$\square$ Isotonic sodium

臣 Cytoflavin

血 Dialipon

[1] Phosphogliv

Glucose solution

Hepadif

Steatel

Lacium

Ursolizin

Fig. 2. The 10 top leaders of TN by the frequency of prescription

ing from chronic hepatitis of the non-viral etiology should be developed in accordance with the current requirements of medical and technological documents that will help the doctor to act effectively in a particular clinical situation, thus avoiding inefficient and error procedures. The new protocol should contain the classified information about the latest methods of pharmacotherapy of patients with $\mathrm{CH}$ caused by drug-induced injury and toxic substances, INNs of drugs for pharmacotherapy of $\mathrm{CH}$, their course doses and dosage forms, as well as criteria for the treatment efficacy evaluation. The use of this approach for the treatment of patients is recommended by the clinical guidelines of the American College of Gastroenterology, which in 2014 issued the clinical guidelines for the diagnosis and treatment of drug-induced liver injuries (Drug-Induced Liver Injury Guidelines) [7].

The formal VEN analysis of the prescribed drugs was conducted to assess the compliance of the therapy of patients with $\mathrm{CH}$ with the regulatory requirements of medical and technological documents. According to the results of VEN analysis conducted using clinical protocols of medical care to patients it was found that 28 of 38 INNs of drugs (73.68\%) were referred to the group V - vital and recommended for use in the pharmacotherapy of the underlying disease and comorbidities. 10 INNs of drugs (26.32\%) and dietary supplements were absent from the CPMC for the pharmacotherapy of the underlying disease and comorbidities.

According to the results of the formal VEN analysis conducted using the NDFU it was found that most of all TNs of drugs prescribed to patients with $\mathrm{CH}$, i.e. $67.0 \%$, were present in this regulation. 39 TNs of drugs (33.0\%) and 12 dietary supplements were absent from the NDFU ( $7^{\text {th }}$ edition). Out of 39 TNs of drugs that received the index $\mathrm{N}$ according to the NDFU (without the evidence base) 15 TNs of drugs were used for the pharmacotherapy of $\mathrm{CH}$ in accordance with the current CPMC indicating the lack of conformity between the regulation and current approaches to the treatment of $\mathrm{CH}$, and therefore, it needs to be updated.

The particular attention was drawn to drugs that were not included in both regulations. The following 14 TNs of drugs $(11.9 \%)$ were referred to them: Osteoarteaze Max (a drug for the treatment of musculoskeletal disorders), Riboxin, Metamax (antiarrhythmic agents of class IB), Dibicor, Mildronate, Mexicor (cardiac drugs), Cyclo-3 fort, L-lysine aescinat (angioprotectors), Traumeel S (homeopathic remedy), Steatel (amino acids and their derivatives), Canephron (complex herbal preparation used in urology), Somaxon, Ceraxon, Vinpocetine (medicines with the neuroprotective effect) and dietary supplements (Gepaval, Gepatomax, Livker, Gepazil, Gynolen, Probiz, Rotabiotic, Forsliv, Selen-Aktiv, Be- targin, Vidzhaysar, Forsal). Most of these drugs belong to metabolic ones and can maintain the liver function to a certain extent, but today the level of evidence of the efficacy of these drugs is insufficient ( $C$ and $D$ levels) to be included in the treatment regimen. The sufficient levels of evidence of the clinical efficacy for drugs in accordance with the current requirements are considered to be $A$ and $B$ levels [1].

Thus, a significant amount of drugs with the index $\mathrm{N}$ according the results of VEN analysis indicates the need for correction of prescribing drugs by doctors of this HCI in accordance with the NDFU and the CPMC by reducing non-essential drugs that are not included in the regulatory medical and technological documents. Considering the fact that in Ukraine the NDFU is a modern document and is updated every year, and the CPMC to patients with $\mathrm{CH}$ is a significantly outdated document, it was necessary to carry out the pharmacotherapy of patients with $\mathrm{CH}$ in this $\mathrm{HCI}$ substantially corresponding to the requirements of the NDFU. Unfortunately, the results of the analysis indicate imperfect therapy of patients with $\mathrm{CH}$ at the $\mathrm{HCI}$ in Dnipropetrovsk. CONCLUSIONS

1. Pharmacotherapy of patients with $\mathrm{CH}$ by the prescribed pharmacotherapeutic groups corresponded to the main areas of the treatment specified in the CPMC. It has confirmed the rationality of most prescriptions, but the average number of prescriptions per a patient is 8.9 TNs, indicating the polypharmacy in this department of the hospital.

2. Being developed 11 years ago, the CPMC to patients with $\mathrm{CH}$ needs to be updated since it does not meet modern requirements to the current science-based medical practice guidelines (does not contain information concerning INNs of the drugs, their course doses and dosage forms, does not contain criteria for the treatment efficacy evaluation, and it is not con- 
sistent with the requirements of evidence-based medicine).

3. Most drug prescriptions for the pharmacotherapy of patients with $\mathrm{CH}$ were drugs included in the NDFU of the $7^{\text {th }}$ edition $(67.0 \%)$ and the Ukrainian CPMC to patients with the underlying disease and comorbidities (73.68\%). It has confirmed the rationality of most drug prescriptions from the clinical point of view, but indicates the need for correction of the $\mathrm{CH}$ pharmacotherapy at the $\mathrm{HCI}$ in Dnipropetrovsk.

\section{REFERENCES}

1. Александров М.А. // Вопросы экспертизы и качества медицинской помощи. - 2011. - №2. - С. 32-38.

2. Бакулин И.Г., Сандлер Ю.Г. // Consilium medicum. Гастроэнтерол. - 2010. - №8. - С. 72-76.

3. Державний формуляр лікарських засобів. Bип. 7. - К.: ДП «Державний експертний центр МОЗ України», 2015. - 1201 с.

4. Клінічний протокол надання медичної допомоги хворим на хронічні гепатити (Наказ МОз України від №271 від 13.06.2005 р.) [Електронний ресурс]. - Режим доступу до сайту: http://www.dec.gov.иа.

5. Морозов А.М., Яковлєва Л.В., Бездітко Н.В. та ін. Оцінка клінічної та економічної доцільності використання лікарських засобів у лікувально-профілактичному закладі (супровід формулярної системи): Метод. рекоменд. - Х.: Стиль-Издат, 2013. - 36 с.

6. Bruce A.R. // Hepatol. - 2013. - Vol. 57, №4. - P. 1651-1678.

7. Naga P.Ch., Paul H.H., Herbert L.B. et al. // Am. J. Gastroenterol. - 2014. - Vol. 109, №7. - P. 950-966.

8. Teo Y.L., Ho H.K., Chan A. // Expert Opin. Drug Metab. Toxicol. - 2004. - №15. - P. 1-12.

9. Topdagi O., Okcu N., Bilen N. // Eurasian. J. Med. - 2014. - Vol. 46 (2). - P. 110-114.

10. Senior J.R. // Drug Saf. - 2014. - Vol. 37, №11. - P. 9-17.

\section{VEN ТА ЧАСТОТНИЙ АНАЛІЗ ЯКОСТІ ФАРМАКОТЕРАПІЇ ХВОРИХ НА ХРОНІЧНИЙ ГЕПАТИТ}

\section{О.В.Ткачова, Н.Т.Т.Фунг, І.В.Завадська*}

Національний фармацевтичний університет, ДЗ «Дніпропетровська медична академія»*

Ключові слова: лікарські засоби для лікування хронічного гепатиту; аналіз якості лікування

Для проведення аналізу якості фармакотерапії 79 хворих на хронічний гепатит (ХГ), які проходили лікування протягом 2015 року у закладі охорони здоров'я (303) м. Дніпропетровська, використовували VEN і частотний аналіз. Встановлено, що фармакотерапія в 303 за призначуваними фармакотерапевтичними групами відповідала основним напрямкам лікування, зазначеним у клінічному протоколі надання медичної допомоги (КПНМД) хворим на ХГ, що підтверджує раціональність лікарських призначень. Але значна кількість призначень на 1 хворого (в середньому 8,9 ЛЗ) свідчить про поліпрагмазію в даному відділенні ЗОЗ. Крім того, за результатами формального VEN-аналізу встановлена значна кількість ЛЗ з індексом N (другорядні засоби), що вказує на необхідність корекції призначень ЛЗ лікарями даного 303 відповідно до науково-медичних нормативних документів: Державного формуляру лікарських засобів Украӥни (7 випуск) і КПНМД хворим на ХГ шляхом зменшення призначень другорядних ЛЗ, що до них не входять. На сьогоднішній день КПНМД хворим на ХГ потребує оновлення, оскільки він розроблений 11 років тому і не відповідає сучасним вимогам до даних науково-медичних нормативних документів, які дозволяють приймати оптимальні клінічні рішення на користь пацієнта згідно з вимогами доказової медицини.

\section{VEN И ЧАСТОТНЫЙ АНАЛИЗ КАЧЕСТВА ФАРМАКОТЕРАПИИ БОЛЬНЫХ С ХРОНИЧЕСКИМ ГЕПАТИТОМ О.В.Ткачева, Н.Т.Т.Фунг, И.В.Завадская*}

Национальный фармацевтический университет, ГУ «Днепропетровская медицинская академия»*

Ключевые слова: лекарственные средства для лечения хронического гепатита; анализ качества лечения

Для проведения анализа качества фармакотерапии 79 больных хроническим гепатитом (ХГ), проходивших лечение в 2015 году в учреждении здравоохранения (УЗ) г. Днепропетровска, использовали VEN и частотный анализ. Установлено, что фармакотерапия в УЗ по назначаемым фармакотерапевтическим группам отвечала основным направлениям лечения, указанным в клиническом протоколе оказания медицинской помощи (КПОМП) больным ХГ, что под- 
тверждает рациональность врачебных назначений. Но значительное количество назначений на 1 больного (в среднем 8,9 ЛС) свидетельствует о полипрагмазии в данном отделении Уз. Кроме того, по результатам формального VENанализа установлено значительное количество ЛС с индексом N (второстепенные средства), что указывает на необходимость коррекции назначений ЛС врачами данного УЗ в соответствии с научно-медицинскими нормативными документами: Государственным формуляром лекарственных средств Украины (7 выпуск) и КПОМП больным ХГ путем уменьшения назначений второстепенных ЛС, которые в них не входят. На сегодняшний день КПомП больным ХГ нуждается в обновлении, поскольку он разработан 11 лет назад и не соответствует современным требованиям к данным научно-медицинским нормативным документам, которые позволяют принимать оптимальные клинические решения в пользу пациента в соответствии с требованиями доказательной медицины.

Address for correspondence:

Received in 18.04.2016

4, Valentynivska str., Kharkiv, 61168, Ukraine.

Tel. (57) 65-88-95. E-mail: ph-econom@nuph.edu.ua.

National University of Pharmacy 